\title{
Konsep Entitas Bagi Usaha Sampingan Ibu Rumah Tangga
}

\author{
Hartati Tuli ${ }^{1}$ \\ ${ }^{1}$ Jurusan Akuntansi, Fakultas Ekonomi, Universitas Negeri Gorontalo, Jl. Jend. Sudirman \\ No. 6 Kota Gorontalo, Gorontalo 96128, Indonesia \\ E-mail: hartati@ung.ac.id ${ }^{1}$
}

Article History:

Received: 01-11-2021

Revised: 05-11-2021

Accepted: 06-11-2021

Keywords: Economic Entity Concept, Housewife

\begin{abstract}
:
The problem in this service activity is the lack of understanding, knowledge and skills of housewives in separating personal wealth and business property or in this case better known as the entity concept. The purpose of this service activity is to improve the understanding and skills of housewives in applying the entity concept in managing their side business. This service activity uses lecture, discussion and direct practic methods. The success of this activity was determined that most of the mothers who had a side business or about $85 \%$ of the participants who took part in this training activity understood and were able to apply the concept of a business entity to the management of their side business.
\end{abstract}

\section{Pendahuluan}

Perkembangan zaman serta kemajuan teknologi yang semakin pesat berbanding lurus dengan meningkatnya kebutuhan hidup masyarakat. Semakin lama biaya hidup semakin meningkat, baik biaya hidup sehari-hari, biaya kesehatan hingga biaya pendidikan. Oleh karena itu untuk menyikapi biaya hidup yang semakin tinggi, seseorang harus memiliki penghasilan yang relative besar agar mampu menutupi kebutuhan hidupnya (Vernia, 2017). Hal ini juga menggugah banyak ibu rumah tangga yang semula hanya fokus untuk mengurusi anak dan suami serta semua hal dalam urusan rumah tangga untuk mulai mengasah kembali skill yang dimiliki dan direalisasikan dalam sebuah kesibukan produktif yang menghasilkan (Anwar et al., 2021).

Anggapan bahwa seorang istri sebaiknya mengurus suami dan anak, agar pekerjaan mencari nafkah menjadi tanggung jawab suami sudah menjadi hal yang umum di Indonesia. Namun, di zaman emansipasi seperti sekarang ini anggapan tersebut sudah tidak berlaku lagi. Perempuan dan laki-laki mempunyai kesempatan yang sama dalam bekerja (Khadijah et al., 2016).

Salah satunya adalah seorang istri yang dapat berperan sebagai pencari nafkah tambahan dengan fungsi membantu suami dalam mencari nafkah. Mencari nafkah tambahan bagi seorang istri tidak harus pergi ke kantor setiap hari, bekerja di rumah pun bisa dilakukan. Misalnya, dengan membuka usaha yang diminati yaitu bisnis online, membuka warung makan, membuka warung kelontong, dan lain-lain.

Berdasarkan fenomena yang terjadi banyak ibu rumah tangga yang melakukan usaha sampingannya, tetapi belum memahami dan menerapkan konsep entitas pada usaha tersebut. Kebanyakan ibu rumah tangga masih menggabungkan antara keuangan usaha sampingannya 
dengan keuangan pribadinya, sehingga menyebabkan kurang jelasnya informasi mengenai perkembangan usaha yang mereka jalankan karena tidak ada pemisahan antara keuangan usaha dengan keuangan pribadinya.

Sesuai dengan Prinsip Akuntansi Berlaku Umum (PABU) mengenai konsep kesatuan usaha (Economic Entity Concept) yang menyatakan bahwa seharusnya entitas harus dianggap sebagai entitas yang berdiri sendiri, terlepas dari pemiliknya. Pemisahan keuangan diri pribadi pemilik usaha dengan kegiatan usaha menjadi hal yang wajib untuk dilakukan agar terjaganya kelangsungan hidup sebuah usaha serta terdapat kejelasan penggunaan barang modal ataupun uang yang digunakan untuk kegiatan operasional usaha dengan kegiatan pribadi pemilik usaha. Masalah ini biasanya timbul dikarenakan pengetahuan dan informasi yang dimiliki ibu rumah tangga mengenai konsep kesatuan usaha (Economic Entity Concept) sangat terbatas (Dermawan et al., 2020).

Pelatihan mengenai konsep entitas ini dilakukan oleh pengabdi sebagai dosen di Program Studi S1 Akuntansi Jurusan Akuntansi Fakultas Ekonomi Universitas Negeri Gorontalo dalam rangka memfasilitasi ibu rumah tangga untuk belajar mengelola usahanya dengan baik dengan cara memberikan pemahaman mengenai pemisahan kekayaan antara milik pribadi dan milik usaha. Sehingga usaha sampingan yang dijalani oleh ibu-ibu rumah tangga di Desa Pentadio Barat akan sesuai dengan standar yang berlaku umum dan memberikan keuntungan yang lebih besar bagi kehidupan perekonomian mereka.

\section{Metode}

Kegiatan pengabdian ini dilakukan dalam beberapa tahap sebagai berikut :

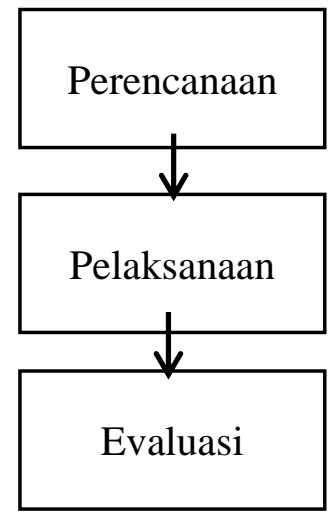

\section{Gambar 1. Tahapan Kegiatan Pengabdian}

1. Tahap perencanaan kegiatan. Pada awal kegiatan ini, tim pengabdi melakukan rapat koordinasi dengan pemerintah setempat yaitu kepala desa Pentadio Barat, merancang prosedur pelaksanaan kegiatan pengabdian, serta menyiapkan undangan untuk dibagikan pada peserta kegiatan pengabdian.

2. Tahap pelaksanaan kegiatan. Pada tahap ini tim pengabdi menyiapkan lokasi pelaksanaan pengabdian, menyiapkan alat dan bahan yang akan digunakan pada saat proses kegiatan berlangsung sampai pada tahap narasumber menjelaskan tentang materi yang akan disampaikan kepada para peserta.

3. Tahap akhir kegiatan. Evaluasi pada akhir kegiatan ini dilakukan untuk mengukur keberhasilan dari seluruh program pengabdian ini. Berdasarkan materi yang telah 
disampaikan oleh pemateri/narasumber peserta diberikan kesempatan untuk melakukan tanya jawab. Kemudian pihak pemateri/narasumber memberikan semacam kuis untuk menguji peserta terkait materi yang telah disampaikan sebelumnya.

Kegiatan ini merupakan kombinasi teoritis yang disajikan secara sederhana. Khalayak sasaran dalam kegiatan pengabdian adalah ibu-ibu rumah tangga yang memiliki usaha sampingan di Desa Pentadio Barat Kecamatan Telaga Biru, Kabupaten Gorontalo. Peserta pada kegiatan ini adalah ibu-ibu rumah tangga yang memiliki usaha sampingan yang berjumlah 16 orang. Adapun metode yang digunakan dalam kegiatan pengabdian ini sebagai berikut:

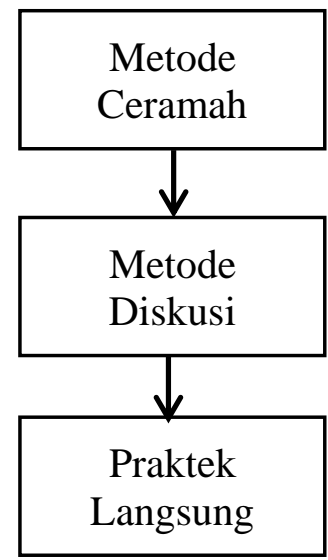

\section{Gambar 2. Tahapan Metode Pengabdian}

1. Metode ceramah digunakan oleh pemateri untuk menjelaskan materi yang berkaitan dengan konsep entitas bisnis dalam pengelolaan usaha.

2. Metode diskusi digunakan untuk memperdalam materi bahasan baik dalam bentuk tanya jawab secara perorangan.

3. Praktek Langsung/Latihan digunakan agar ibu-ibu rumah tangga mampu mengaplikasikan konsep entitas pada pengelolaan usaha sampingannya

\section{Hasil}

Kegiatan pengabdian masyarakat ini diawali dengan persiapan pelaksanaan kegiatan yang dimulai dengan koordinasi dengan pemerintah setempat, penyusunan program, serta penyebaran undangan kepada ibu-ibu rumah tangga di desa Pentadio Barat. Selanjutnya adalah tahap pelaksanaan dimana tim pengabdi mempersiapkan lokasi pelaksanaan kegiatan pengabdian, dalam hal ini lokasi yang digunakan adalah rumah salah satu masyarakat desa Pentadio Barat yang menjadi peserta dalam kegiatan ini, selanjutnya mempersiapkan media presentasi yaitu infocus/LCD serta powerpoint yang didalamnya terdapat materi yang dilengkapi dengan contoh konkret agar peserta dapat lebih memahami materi yang disampaikan.

Dalam kegiatan pengabdian ini, pemateri atau narasumber menyampaikan materi yang terdiri dari apa yang dimaksud dengan konsep entitas, apa saja yang ada dalam konsep entitas serta bagaimana penerapannya dalam kehidupan sehari-hari.

Kegiatan pengabdian berlangsung selama kurang lebih dua jam dan dilanjutkan 
dengan kegiatan diskusi antara peserta dan narasumber. Pada sesi diskusi ini para peserta terlihat sangat antusias, hal ini dilihat dari banyaknya pertanyaan yang diajukan oleh peserta terkait materi yang telah disampaikan oleh narasumber sebelumnya. Dalam sesi ini, para peserta menyampaikan permasalahan-permasalahan yang mereka hadapi terkait pemisahan kekayaan sendiri dan milik usaha. Melalui sesi diskusi ini telah tercipta ruang dan suasana kedekatan antara peserta dan tim pengabdi. Banyak peserta yang menyampaikan saran kepada tim pengabdi agar kegiatan seperti ini terus dilakukan dalam rangka meningkatkan pemahaman mereka dalam pengelolaan usahanya. Pada akhir kegiatan peserta dan tim pengabdi makan bersama makanan yang telah disiapkan oleh tim pengabdi.

\section{Diskusi}

Konsep entitas binis adalah asumsi dasar akuntansi keuangan karena konsep ini membatasi data ekonomi dalam system akuntansi ke data yang berhubungan langsung dengan aktivitas usaha. Dengan kata lain, bisnis dipandang sebagai entitas terpisah dari pemilik, kreditor, atau pihak pemangku kepentingan lainnya (Rodiah et al., 2020).

Konsep entitas merupakan konsep yang penting dalam penyelenggaraan akuntansi, konsep ini menyatakan bahwa antara kesatuan usaha yang satu dengan kesatuan usaha yang lain atau dengan pemiliknya harus terdapat garis pemisah yang tegas, hal ini berarti kejadian keuangan yang menyangkut suatu kesatuan usaha lain atau dengan pemiliknya, dan sebaliknya (Dermawan et al., 2020).

Dalam menjalankan usaha, tidak hanya seorang ayah atau laki-laki saja yang melakoninya. Saat ini banyak perempuan yang memerankan peran ganda dalam kehidupannya, yaitu sebagai ibu rumah tangga dan wanita bekerja. Meskipun memiliki karir di dunia kerja sekaligus mengurus rumah tangga dan anak adalah pekerjaan yang sulit dilakukan secara bersamaan, banyak juga yang memilih untuk tetap melakoni hal tersebut demi mendapatkan penghasilan tambahan untuk memenuhi kebutuhan mereka (Elburdah et al., 2021). Ada berbagai macam motivasi yang melatar belakangi seorang ibu rumah tangga akhirnya memutuskan untuk memiliki usaha. Motivasi bisnis para ibu rumah tangga diantaranya (Vernia, 2017) :

1. Membantu suami dalam pemenuhan kebutuhan ekonomi keluarga

2. Mengisi waktu luang

3. Menyalurkan hobi

4. Adanya keinginan untuk berprestasi

Dalam kegiatan pengabdian yang telah dilakukan di Desa Pentadio Barat, tim pengabdi menemukan beberapa macam persoalan yang dialami oleh ibu rumah tangga dalam menjalankan usahanya. Salah satu masalah yang paling banyak dialami oleh mayoritas ibu rumah tangga yang memiliki usaha sampingan adalah belum adanya pemahaman mengenai cara memisahkan antara kekayaan pribadi dan kekayaan usahanya. Dari tahap diskusi yang dilakukan tim pengabdi, ibu-ibu rumah tangga mengatakan bahwa semua kekayaan baik pribadi maupun usahanya disatukan, sehingga tidak ada pemisahan antara hasil dari usaha dan aset pribadi yang tidak ada hubungannya dengan usaha. Hal ini tentu membuat hasil perolehan usaha tidak menggambarkan keadaan yang sebenarnya. Hal tersebut didukung oleh pernyataan Irawan \& Wardhani (2021) yang menyatakan bahwa terkadang beberapa pelaku usaha merasa usaha mereka berjalan normal namun sebenarnya usaha mereka tidak mengalami perkembangan. Ketika ditanyakan mengenai laba yang diperoleh setiap periode, 
mereka tidak bisa menunjukkan dengan nominal angka melainkan dengan aset berwujud seperti tanah, rumah atau kendaraan. Padahal aset tersebut didapatkan tidak hanya dengan dana usaha mereka tetapi terkadang ditambah dengan harta pribadi. Aset tersebut juga terkadang bukan digunakan untuk kepentingan usaha tetapi untuk kepentingan pribadi. Agar dapat mengetahui perkembangan usaha hal pertama yang harus dilakukan adalah memisahkan keuangan pribadi dan keuangan usaha.

Oleh karena itu, dalam kegiatan pengabdian ini pengabdi berusaha untuk memberikan pemahaman bagi ibu rumah tangga yang memiliki usaha sampingan untuk selalu memisahkan antara penerimaan dan pengeluaran usaha dengan penerimaan maupun pengeluaran pribadi. Narasumber dalam kegiatan pengabdian ini menghimbau agar ibu rumah tangga selaku pemilik usaha untuk selalu melakukan pencatatan, agar semua kegiatan usaha terekam dengan jelas dan dapat dievaluasi apakah dalam usahanya terdapat keuntungan atau malah kerugian. Dengan adanya catatan yang jelas maka tentu akan memudahkan pelaku usaha untuk menilai keberhasilan usahanya.

\section{Kesimpulan}

Setelah proses pelatihan berlangsung, maka dapat dilihat bahwa sebagian besar peserta pelatihan yang ikut dalam kegiatan ini dapat memahami apa yang dimaksud dengan konsep entitas dalam pengelolaan usaha. Kegiatan pengabdian seperti ini perlu terus dilakukan oleh para dosen Fakultas Ekonomi dan fakultas lain yang ada di Universitas Negeri Gorontalo sebagai wujud pengabdian kepada masyarakat. Hal ini sejalan dengan program pemerintah dalam mewujudkan masyarakat yang mandiri dan berdaya saing.

\section{Pengakuan/Acknowledgements}

Terima kasih kepada seluruh pihak yang telah memberikan kontribusi baik secara langsung maupun tidak langsung sehingga kegiatan pengabdian ini dapat terlaksana dengan baik. Terima kasih kepada Kepala Desa Pentadio Barat yang telah memberikan kesempatan bagi pengabdi untuk melaksanakan kegiatan pengabdian ini, dan teristimewa kepada ibu-ibu rumah tangga yang telah bersedia menjadi peserta pengabdian. Semoga apa yang telah disampaikan dalam kegiatan pengabdian ini dapat memberikan manfaat bagi masyarakat desa Pentadio Barat khususnya ibu-ibu rumah tangga dalam mengelola usaha sampingannya.

\section{Daftar Referensi}

Anwar, S., Sofiatun, S., Yulita, D., Sesriyani, L., Rusmaini, \& Apriliani, F. (2021). Pelatihan Pengelolaan Bisnis Salon Kecantikan Bagi Ibu Rumah Tangga yang Mengambil Kursus d LKP Daya Insan Nusantara Abadi. Pekodimas: Jurnal Pengabdian Kepada Masyarakat, 6(1), 72-79.

Dermawan, W. D., Prawiranegara, B., \& Rozak, D. A. (2020). Penerapan Konsep Entitas Dalam Meningkatkan Perkembangan Usaha Mikro Kecil Dan Menengah. ISEI Accounting Review, IV(1), 26-29.

Elburdah, R. P., Pasaribu, V. L. D., Rahayu, S., Septiani, F., \& Metarini, R. R. A. (2021). 
Mompreneur Penopang Perekonomian Keluarga Di Masa Pandemi Covid-19 Dengan Bisnis Online Pada Kelurahan Pondok Benda. Jurnal Pengabdian Kepada Masyarakat, 2(1), 75-82. http://www.openjournal.unpam.ac.id/index.php/JAL/article/view/8776

Irawan, W., \& Wardhani, R. S. (2021). Economic Entity Concept, Penata Keuangan dan Aplikasi Lamikro Era Industri 4.0 (UMKM Provinsi Kepulauan Bangka Belitung). Jurnal Akuntansi, 13(1), 23-45. https://doi.org/10.28932/jam.v13i1.3001

Khadijah, U. L. S., Rejeki, D. S., Sukaesih, \& Anwar, R. K. (2016). Literasi Informasi Motivasi Berwirausaha Ibu Rumah Tangga Kelurahan Nagasari Kabupaten Karawang Barat. Jurnal Kajian Informasi Dan Perpustakaan, 4(2), 149. https://doi.org/10.24198/jkip.v4i2.8491

Rodiah, S., Ramashar, W., \& Azmi, Z. (2020). Program Kemitraan Masyarakat Stimulus Rumah Jahit Nia. Jurnal Pengabdian UntukMu NegeRI, 4(1), 35-39. https://doi.org/10.37859/jpumri.v4i1.1782

Vernia, D. M. (2017). Optimalisasi Media Sosial Sebagai Sarana Promosi Bisnis Online Bagi Ibu Rumah Tangga Untuk Meningkatkan Perekonomian Keluarga. Jurnal Ilmiah Pendidikan Dan Ekonomi, 1(2), 105-118. http://journal.stkipnurulhuda.ac.id/index.php/utility/article/view/71 